\title{
芺薬甘草湯内服中に低カリウム血症による心室細動を繰り返 した一例
}

$\begin{array}{llrllll}\text { 酒井規広 } & \text { 酢谷 } & \text { 朋子 } & \text { 上松 } & \text { 友希 } & \text { 大崎 } & \text { 友宏 } \\ \text { 垂石智重子 } & \text { 鈴木 } & \text { 照 } & \text { 高田 } & \text { 基志 } & \text { 宮部 } & \text { 浩道 }\end{array}$

総合大雄会病院麻酔科 ( $\mathbf{T} 491-8551$ 愛知県一宮市桜 1-9-9)

Key words: (1) licorice, (2) hypokalemia, (3) ventricular fibrillation

\section{はじめに}

药薬甘草湯は, こむら返りや筋痤攣を伴う筋肉痛に 効果がある漢方薬である。药薬甘草湯にはグリチルリ チンが含まれており，低カリウム血症の原因となりう る。我々は, 药薬甘草湯を連用した結果, 低カリウム 血症誘発と考えられる心室細動を繰り返した症例を経 験したので報告する。

\section{症 例}

83 歳, 男性。身長 $160 \mathrm{~cm}$ ，体重 $69 \mathrm{~kg}$ 。高血圧に対 してアムロジピン $5 \mathrm{mg}$, フロセミド $20 \mathrm{mg}$ を内服し ていた。ある日外出先で意識消失発作を起こして転倒 し, 顔面を強打して当院救命救急センターに来院した。 来院時の意識は清明であった。心電図は洞調律で あったが (Fig. 11)，診察中に意識消失とともに心室 細動を認めた。即座に胸骨圧迫と除細動を施行し, 洞 調律に復帰した。血液検査でカリウム $2.0 \mathrm{mmol} / l$ の 著明な低カリウム血症を認めた。尿素窒素は $9.3 \mathrm{mg} /$ $\mathrm{d} l$, 血中クレアチニンは $0.9 \mathrm{mg} / \mathrm{d} l$ であった。循環器 内科医の診察で, 虚血性心疾患を疑い, アミオダロン を持続静注しながら心臓カテーテル検査を施行した が, 明らかな冠動脈狭窄を認めなかった。検査後, ICUに入室した直後に再び意識消失と心室細動を認め た (Fig. 1(2))。その後も断続的に心室細動を繰り返し, 10 秒ほどで洞調律に復帰するが，30秒以上復帰しな いこともあり, 計 10 回の除細動を要した。

後から病院に到着した家族からの情報で，長期にわ
たり漢方薬を服用していることが判明し，家族が持参 した薬剤手帳から, 药薬甘草湯 1 日 $7.5 \mathrm{~g}$ を 8 ケにわ たって連用していたことを確認した。中心静脈カテー テルを挿入してカリウム補正を行った。また，フロセ ミドは中止し, スピロノラクトン $200 \mathrm{mg}$ 静注, 硫酸 マグネシウムも投与した。入室後約 24 時間で, 1 日 あたり $100 \mathrm{mmol}$ 以上の投与にならないように, 10 $\mathrm{mmol} / \mathrm{hr}$ のカリウム補正を間歇的に継続し, カリウム 濃度は $2.0 \mathrm{mmol} / l$ から $2.8 \mathrm{mmol} / l$, さらに 24 時間後 に3.7 mmol/l $l$ まで改善した。心電図波形上, 40〜 $50 /$ minの徐脈が継続し，U波の増高を認めたため (Fig. 1 (3)および(3)')，一時アドレナリンの持続静注を行った が，脈拍増加を認めなかった。イソプロテレノールの 持続静注を開始したところ, 脈拍数も $80 \sim 100 / \mathrm{min}$ を維持，心室細動も消失した (Fig. 14)～(6))。

併発した誤曣性肺炎の治療を行い，入室9日目に ICUを退室した。退院前に測定された血中アルドステ ロンは $68.5 \mathrm{pg} / \mathrm{ml}$, 血漿レニン活性は $0.7 \mathrm{ng} / \mathrm{ml} / \mathrm{hr}$ で あった。カプトプリル負荷試験後, 血中アルドステロ ンは63.6 pg/ml, 血漿レニン活性 $1.1 \mathrm{ng} / \mathrm{ml} / \mathrm{hr}$, アル ドステロン/レニン比58であり, カプトプリル負荷試 験は陰性であった。全身 CTでも原因となりうる副腎 腫瘍などは指摘されず, カンゾウによる偽性アルドス テロン症と診断された。

\section{考察}

药薬甘草湯に含まれるカンゾウは, 疼痛緩和に有効 とされる生薬の一つで, グリチルリチンを含み, 多量

Hypokalemia with recurrent ventricular fibrillation during licorice administration: a case report

Norihiro Sakai, Tomoko Sudani, Yuki Uematsu, Tomohiro Ohsaki, Chieko Taruishi, Akira Suzuki, Motoshi Takada, Hiromichi Miyabe

Department of Anesthesia, Daiyukai General Hospital(1-9-9 Sakura, Ichinomiya, Aichi 491-8551, Japan)

J Jpn Soc Intensive Care Med 2017;24:555-6. 


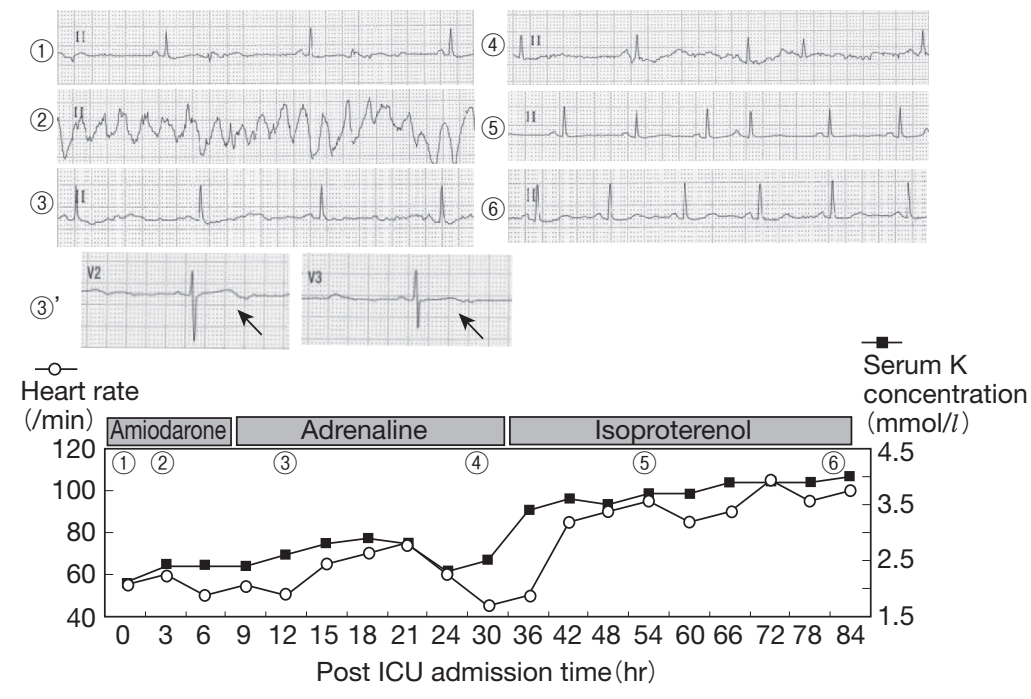

Fig. 1 Clinical course and electrocardiogram in ICU
摂取は偽性アルドステロン症を来し, 低カリウム血症 をもたらす。カンゾウの長期内服によりさまざまな副 作用を呈し, さらに摂取量が少量でも致死性不整脈を 来した症例が報告されている1),2)。本症例の患者は 1 日あたりのカンゾウ摂取量が $6 \mathrm{~g}$ であり，長期にわた る連用のために, 偽性アルドステロン症の発症と低力 リウム血症の遷延が顕在化したと考えられた。

本症例では, 本人の発言が曖昧であったため, 家族 からの情報と薬剂手帳で初めて药薬甘草湯の内服歴が 明らかとなり, 偽性アルドステロン症を疑うきっかけ になった。市中ではカンゾウを含む減量目的の健康食 品が容易に入手できる上, 1日のグリチルリチン摂取 量 $200 \mathrm{mg}$ (カンゾウ換算 $5 \mathrm{~g}$ ) 程度で, 偽性アルドステ ロン症をはじめとする種々の副作用を来す可能性も指 摘されていることから, 低カリウム血症を起こしうる 食品, 薬剤の内服の可能性について常に疑うべきであ る3),4)。

本症例は高血圧治療に対してカルシウム拮抗薬と ループ利尿薬が併用されていたが, 抗アルドステロン 薬やレニン・アンギオテンシン系阻害薬を併用しない ループ利尿薬の使用も, 低カリウム血症を誘引しやす いため, 注意が必要である。

ICU入室時は著明な徐脈を呈しており，心電図上に QT延長を認め $(\mathrm{QTc}=463 \mathrm{msec})$, さらにU波の増高 と T波の融合による TU波とおぼしき波形を認めた (Fig. 1 (3および3) の矢印)。Torsades de Pointesを 疑い, 後天的 QT 延長症候群と同様の治療方針が妥当 であると判断した。ガイドラインに従い, 一時ペーシ ングを考慮したが5), 体外式ペースメーカーを準備す ることができず，やむなく硫酸マグネシウムの投与と イソプロテレノールによる脈拍コントロールを行っ た。さらに慎重なカリウム補正により, Torsades de
Pointesおよび心室細動の発生もみられなくなった。 致死性不整脈の発生が連続する場合, 原因となる薬剂 を中止し, 硫酸マグネシウムの投与, および本来であ れば一時ペーシングを早急に行うべきである。

ICU 退室後のカプトプリル負荷試験および全身検索 で, 副腎腫瘍など原発性アルドステロン症を疑わせる 所見を認めなかった。過去の病歴や薬剤歴から, 偽性 アルドステロン症を強く疑わせる経過であったが, 常 に原発性疾患の存在を考慮において治療を進めるべき である。

本症例は発表に際し患者家族の同意を得た。

本稿の全ての著者に規定されたCOIはない。

\section{文 献}

1) Erikosson JW, Carlberg B, Hillörn V. Life-threatening ventricular tachycardia due to liquorice-induced hypokalaemia. J Intern Med 1999;245:307-10.

2) Panduranga P, Al-Rawahi N. Licorice-induced severe hypokalemia with recurrent torsade de pointes. Ann Noninvasive Electrocardiol 2013;18:593-6.

3) Nazeri A, Massumi A, Wilson JM, et al. Arrhythmogenicity of weight-loss supplements marketed on the Internet. Heart Rhythm 2009;6:658-62.

4) Sontia B, Mooney J, Gaudet L, et al. Pseudohyperaldosteronism, liquorice, and hypertension. J Clin Hypertens 2008;10:153-7.

5) 大江 透, 相澤義房, 新 博次, 他 ; 日本循環器学会, 日本 心臟病学会, 日本心電学会, 他. QT延長症候群 (先天性 · 二次性) とBrugada症候群の診療に関するガイドライン. Circulation J 2007;71:1205-53. 